\title{
Safeguarding what and for whom? The role of institutional fit in shaping REDD+ in Mexico
}

\author{
Constance L. McDermott ${ }^{1}$ and Claudia Ituarte-Lima ${ }^{2}$
}

\begin{abstract}
This paper examines the UN Framework Convention on Climate Change mechanism Reducing Emissions from Deforestation and Degradation (REDD+), and its associated multitude of global to local safeguards, as they apply to a single ejido on the Yucatan Peninsula, Mexico. It draws on written sources and interviews to analyze the ways in which broad international norms articulated through the REDD+ safeguards, including support for human rights and sustainable livelihoods for local communities, are translated at national, regional, and local levels. Our findings indicate a wide range of perspectives on what constitutes sustainability, from strict conservation to more forest use-oriented strategies, such as community forestry and traditional Mayan shifting cultivation. These visions, in turn, shape what types of REDD+ interventions are considered a good "environmental fit," i.e., that fit the environmental problems they aim to address. Fits and misfits also occur between institutions, and play a core role in determining whose visions of sustainability prevail. We found a good fit in the case study ejido between REDD+ and the Payment for Ecosystem service (PES) scheme, which sets the parameters for what counts as "sustainable livelihoods" within a strict conservation paradigm. We likewise found a good fit between REDD+ safeguards and institutions supporting local community rights to reject REDD+ projects. However, despite the strength of procedural safeguards, the parameters of the PES scheme constrained the choice of REDD+ activities available, including the possibilities of local people to work on the farm and in the forest, and hence the scope of its distributive benefits. This highlights the important, but also problematic, roles of institutional and environmental "fit" in determining whose rights are safeguarded and what is recognized as a sustainable livelihood strategy. It also calls for more proactive efforts to expand the range of REDD+ activities in ways that safeguard livelihood diversity.
\end{abstract}

Key Words: community forest; free, prior, and informed consent (FPIC); governance; REDD+; safeguard;

\section{INTRODUCTION}

The concept of "safeguards" is proliferating within international discourse as a means to address the environmental and social risks of international intervention at local scales, and to ensure sustainable outcomes. The appeal of REDD+ safeguards under the UN Framework Convention on Climate Change (UNFCCC) for international actors is clear: they allow the prioritization of particular international goals, such as emissions reductions, while acknowledging others, such as biodiversity and the welfare of local communities (McDermott et al. 2012). ${ }^{[1]}$ However, what do "sustainability" and "safeguarding" actually mean to different actors? And what are the roles of institutions in shaping the parameters of what is considered sustainable, whose rights are prioritized, and how safeguards are translated into national and local realities?

To answer these questions we draw on a multiscale study of reducing emissions from deforestation and degradation (REDD+) rooted in a single Mexican ejido on the Yucatan Peninsula. REDD+ is a climate mitigation mechanism under UNFCCC that has developed a broad set of international safeguards calling for the protection and enhancement of local rights, participation, and sustainable livelihoods. Understanding how REDD + is operationalized, and how its safeguards are enacted, requires an analysis of the ways in which REDD+ is interpreted and transformed across a multitude of scales. We therefore root this research in a single case study, and then "look upward" toward the plethora of institutions shaping REDD+ activities in the study area, from the local to the global level. This identifies an assemblage of institutions whose precise composition and interplay will vary from one location to the next. Consistent with this approach, our goal is not to predict how REDD+ will unfold worldwide or nationally, but rather to better understand the processes by which diverse institutions mediate local REDD+ outcomes.

Our analysis is organized around the concepts of "institutional" and "environmental" fit as explanatory frameworks for understanding why REDD+ unfolds in particular ways in particular contexts, and what this implies for social equity. The idea of institutional fit has roots in "new institutionalism," a theoretical approach that focuses on how institutions are shaped by their political, social, and cultural environments (March and Olsen 1983, Powell and DiMaggio 1991). From this perspective, the concept of "fit" addresses the degree to which different types of policies or interventions fit, or align, with the goals, needs, norms, and structures of existing institutions (Wright and Snell 1998). Inherent in this conception of "fit" is an awareness of institutional power dynamics, and how good fit, although it may increase the likelihood of uptake, can also entrench existing power structures (Wright and Snell 1998). Likewise in our study, we are interested in the degree of fit or misfit between REDD+ and each of its associated safeguards with the existing and/or emerging institutions responsible for implementing REDD+ in Mexico, and how this impacts the balance of power and voice in the process. 
The concept of "environmental fit," as pioneered by Young and others (Young 2002, Young et al. 2008), draws on theories of institutional fit to argue that the effectiveness of institutions also depends on their fit with the nature of the environmental problems they aim to address. Various authors have identified a range of different dimensions across which such environmental fits or misfits might occur, e.g., spatial, temporal, social-ecological, etc. (Cox 2012, Epstein et al. 2015). However, as will become clear from our analysis, the degree of fit between REDD+ institutions and the problems they aim to address depends, first and foremost, on how those problems are defined. In other words, "environmental fit" is inherently socially constructed (Bromley 2012, Vatn and Vedeld 2012). Coming from this perspective, the focus of our analysis of environmental fit, is on whether the institutionalization of REDD+ is reinforcing certain visions of sustainability over others, and the implications this has for social equity.

Such a constructionist perspective resonates well with a parallel understanding of "equity," as likewise judged through the eyes of the beholder. Similarly to McDermott et al. (2013), we view equity as multidimensional, and embedded first and foremost in the overarching question of who sets the goals or "parameters" for environmental governance, such as the definitions of sustainability that explicitly or implicitly accompany REDD+ activities. We also draw on McDermott et al. (2013) to distinguish this initial parameter or goal-setting from the issues of procedural and distributive equity in the implementation of REDD+. Within these latter dimensions, we consider who is included and excluded in REDD+ decision-making (procedural equity) and what this means for the distribution of costs and benefits (distributive equity).

This type of analysis is critical if we consider that REDD+ is a highly dynamic phenomenon that is evolving differently and has distinctive equity implications in different locations (see, e.g., Ituarte-Lima et al. 2014). As it was first conceived at the international level, REDD+ had no express social goals, beyond perhaps those embedded in a neoliberal market logic. REDD+ first emerged under the UNFCCC as an economic incentive mechanism to pay developing countries to reduce deforestation, with substantial support from developed countries. The rationale was that tropical deforestation accounted for an estimated $17 \%$ of global greenhouse gas emissions (Stern 2007) and that paying to reduce forest loss offered a relatively fast and cheap way to reduce global emissions (Eliasch 2008).

However, a wide range of stakeholders were concerned that REDD+, by assigning a new monetary value to forest carbon, would set off a cascade of inequitable impacts, including land grabs and the dispossession of local and indigenous peoples, the loss of local livelihoods and loss of biodiversity (Sikor et al. 2010, McDermott et al. 2012). In response to these concerns, the REDD+ Cancun Agreement (UNFCCC/AWGLCA 2011) introduced its list of seven "safeguards."

Of the seven REDD+ safeguards, three are of central concern to this paper because they relate directly to local community welfare. These are safeguards (c) respect for the rights of indigenous peoples and local communities, (d) full and effective community participation, and (e) enhancement of environmental and social benefits and local livelihoods (see Box 1).

\section{Box 1: The UNFCCC REDD+ Safeguards}

c) Respect for the knowledge and rights of indigenous peoples and members of local communities, by taking into account relevant international obligations, national circumstances and laws, and noting that the United Nations General Assembly has adopted the United Nations Declaration on the Rights of Indigenous Peoples;

d) The full and effective participation of relevant stakeholders, in particular indigenous peoples and local communities, in the actions referred to in paragraphs $70^{1}$ and $72^{2}$ of this decision;

e) That actions ... enhance other social and environmental benefits $^{3}$

1 "Encourages developing country Parties to contribute to mitigation actions in the forest sector by undertaking the following activities ... a) reducing emissions from deforestation; b) reducing emissions from forest degradation; c) conservation of forest carbon stocks; d) sustainable management of forests; e) enhancement of forest carbon stocks..."

2 "Also requests developing country Parties, when developing and implementing their national strategies or action plans, to address, inter alia, the drivers of deforestation and forest degradation, land tenure issues, forest governance issues, gender considerations and the safeguards ..."

3 "Taking into account the need for sustainable livelihoods of indigenous peoples and local communities and their interdependence on forests in most countries, reflected in the United Nations Declaration on the Rights of Indigenous Peoples, as well as the International Mother Earth Day."

Agreement on the REDD+ safeguards helped expand the range of stakeholders supportive of, and potentially involved in, REDD+ decision making, while also fuelling debate on its scope and complexity (Visseren-Hamakers et al. 2012). This expansion of the scope of REDD+ to include safeguards, together with long delays in the resolution of a post-Kyoto climate agreement, was accompanied by an expansion of institutions involved in operationalizing or framing REDD+. At the global level, these range from multilateral global and regional finance agencies such as the World Bank's Forest Carbon Partnership Facility (FCPF) to UN consortiums such as the UN-REDD Programme, to private forest carbon certification schemes and "hybrid" public/ private partnerships such as the REDD+ Environmental and Social Standards (REDD+ SES) initiative. These various international REDD+-related institutions have developed a wide range of safeguard-related policies and standards, which vary in their content and emphasis (McDermott et al. 2012).

These international safeguards interact, in turn, with relevant regional, national, and local policies and priorities. As stated in the REDD+ Cancun agreement (UNFCCC 2011) and subsequent Decisions (e.g., UNFCCC Decision 12/CP.17), national governments hold the ultimate authority over the implementation of REDD+ within their borders. Hence the development of national policy on REDD+ can play a central 
role in the overall framing of REDD+ goals. Mexico's REDD+ Vision (CONAFOR 2010) recognizes the importance of environmental protection and community rights, sustainable rural development, and climate mitigation.

Given Mexico's very broad framing of REDD+, it is difficult to separate the question of "safeguarding" from broader issues of environmental, social, and economic sustainability as goals in and of themselves. We found the same thing to be true, only more so, at the local level. That is, the norms, policies, and actions relevant to safeguards are not viewed or framed as safeguards per se. Thus our study of local-level safeguarding considers not just formal written safeguards articulated in the various international institutions and national laws implementing REDD+-related activities in the area, but also local-level policies and actions that address issues of relevance to the REDD+ safeguards.

\section{METHODS}

The geographic focal point of the study is the ejido Felipe Carrillo Puerto in the state of Quintana Roo, on Mexico's Yucatan Peninsula. Ejidos are community groups that hold a combination of communal and individual land rights and participate in collective land and resource management systems. As dictated under the Mexican Agrarian Law (see Article 22 and Article 10, respectively), ejidos are governed by communal "Assemblies" (Asambleas) that operate under "internal regulations" (reglamentos internos). The existence of a well-established and relatively formalized local governance structure makes ejidos particularly interesting subjects to examine in the context of multilevel REDD+ governance, because their strong communal rights might be expected to result in a relatively strong voice in local REDD+ decision making.

We chose to focus our study within the Yucatan Peninsula because of its unique engagement with REDD+. First, it was the city of Cancun that hosted UNFCCC COP 16 where international REDD+ and the associated safeguards were first agreed (see Box 1). Second, it has attracted a relatively high diversity of REDD+ activities. Although the bordering state of Chiapas has a longer history of engagement with forest carbon markets (Corbera and Brown 2008, Osborne 2011), carbon trading is only one type of REDD+ activity and one that appeared to be generating considerable conflict among stakeholders in that state. In contrast, we found stakeholders in the Yucatan more open and interested in sharing their views.

Within the Peninsula, the ejido of Felipe Carrillo Puerto, hereafter abbreviated to "FCP"[2], was chosen as a relatively advanced example of project-level implementation in the region (Proust 2011). It is, however, far from a "typical" ejido. The total land area of FCP is 47,000 hectares, which is much larger than the average Mexican ejido. There are only 200 ejidatarios in total (EFCP 2005), giving it a much lower than average density of ejido members per hectare. Of particular relevance to the REDD+ safeguards, local poverty rates are relatively high, many of the ejidatarios are indigenous Mayans, and the ejido lies adjacent to the Sian Ka'an Biosphere Reserve, an area with flooded forests, savannah, and mangroves known for high levels of biodiversity (Proust 2011). The combination of low population density and high rates of poverty would appear to make REDD+ relatively easy to implement, because of lesser internal pressures for forest use and conversion and lower opportunity costs. At the same time the presence of indigenous Mayan peoples and the location of the ejido next to an area of high conservation value, as well as risks of urban expansion in part of the ejido, might help explain why the area has attracted significant international support for REDD + activities. Thus if FCP has faced challenges in implementing REDD+-related activities and safeguards, many of those challenges might be expected to be as large or larger elsewhere in the Yucatan.

The data collected for our research includes a combination of primary and secondary written sources, 27 semistructured interviews, five focus group meetings, field trips, and participant observation in national and subnational REDD+ related meetings in Mexico. The primary objectives of the interviews, focus groups, and participant observation, were to map out the development of REDD+ at multiple scales, identify key stakeholders involved in these developments, and compare and contrast world views and perspectives. The comparison of world views was not exhaustive, but rather aimed to classify a range of commonly held views and examine the degree to which these world views fit with the priorities and actions of REDD+ institutions. We then drew on interviews, written documentation, as well as secondary literature to further elaborate a list of key institutions associated with REDD+ activities in our case study area. The focus was on the on-the-ground activities to which safeguards would presumably apply, and does not include activities focused solely on networking or information dissemination. Our subsequent analysis of institutional and environmental fit, and social equity, was based on the range of available evidence from interviews and written documents. In other words, these findings are based on our independent analysis and do not represent the views of any particular group of stakeholders.

The interview and focus group respondents were identified through snowball sampling among the organizations and agencies involved in REDD+-related safeguarding activities at national and regional (Yucatan Peninsula) levels, including governmental institutions as well as civil society organizations (both national and international). At the local level, interviewees included people who had participated in the development of the Much Kanan K'aax (MKK) project and/or who were currently developing other $\mathrm{REDD}+$ related activities. The interviews were primarily conducted in Spanish, recorded, and transcribed; in most cases, the quotes included in this paper have been translated into English.

Most of the field data for this study was collected between February to April 2013 and January to April 2014. We recognize that the development of REDD+ in Mexico is highly dynamic and evolving, and encourage ongoing research into when, why, and how REDD+ priorities and institutions change over time.

\section{RESULTS}

\section{Defining sustainability}

REDD+ safeguard (e) calls for enhancing environmental and social benefits and taking into account sustainable livelihoods (see Box 1). However achieving these goals requires, first and foremost, a normative perspective or vision on precisely what sustainability is, and what actions will generate the environmental 
and social benefit needed to achieve it (e.g., Clapp and Dauvergne 2005). It became abundantly clear in our interviews, and was in fact strongly emphasized by some of the interviewees themselves, that there is a wide range of contrasting perspectives on these issues.

For the purpose of comparison, we identified three broad categories of perspectives on sustainability. These categories are not exhaustive of all views expressed, nor are they necessarily representative of any particular stakeholder group, but they are nevertheless indicative of much of the variation encountered. This yielded the following categories, which we have labelled as: "No Touch," "Humans in Nature," and "Traditional Use." Although there was some overlap among the latter two categories in particular, the classification highlights the level of emphasis placed on different explanatory pathways.

The No Touch (strict conservation) perspective was most strongly articulated by an interviewee within the Mexican Commission on Natural Protected Areas (CONANP). From this perspective, local forest users and their traditional practices constitute the greatest threat to forest conservation. The route to sustainability, therefore, is to develop alternative livelihood strategies not dependent on local resource use. The following excerpt is indicative of this perspective:

The ejidatarios also recognize that the major risk to the forest, well, is fire... And what is the cause of the fire? Slash and burn agriculture and hunting - they themselves do it. They themselves are the hunters and they themselves slash and burn in order to plant afterwards. That is the practice that is most terrible. Why do they do it? "It is our custom" ... We obviously need to implement [income] diversification strategies... that help reduce this risk... to biodiversity. Interviewee 3, Government.

A second perspective is what we categorize as the Humans in Nature worldview. This perspective emphasizes the importance of sustainable, community-based forestry and/or local enterprise development based in active forest use and management. These respondents also tended toward skepticism or outright rejection of the role of carbon payments in fostering sustainable behavior in Mexico.

We don't want a no touch REDD... a super program of payments and [sic] environmental services for not touching the forest. Because this would destroy governance, destroy capacities to regenerate the forest. People will simply abandon the forest... We would like the money to support the active management of forests, the productive management... not carbon. Interviewee 9 , National NGO.

What we want is for communities to start managing their forest, not thinking in carbon, but thinking about products; so wood or honey or whatever. And so producing something and selling it to the market. So carbon, for me, has been something very ethereal, you know? Like, not very, you don't really know, and the Kyoto, post-Kyoto and the carbon price are going down. So, I don't really see that it's going to be making communities wealthier. Interviewee 30, National NGO.
Finally, the Traditional Use perspective was mostly articulated by interviewees stationed in the Yucatan working variously for locally based and international NGOs. The emphasis here is on the role of indigenous Mayan culture as the key to sustainability.

\section{[We want to] enrich the concept of the local, nothing more, it is the best safeguard ... all of the peninsula, the diversity which we have to enjoy has been with the Mayans always, since 3000 years... Mayans know very well how to manage the forests. Interviewee 22, International NGO.}

Another interviewee with a Traditional Use perspective viewed a need for REDD+ safeguarding that would better articulate the values and principles of peoples' customary rights. In referring to limitations s/he viewed in safeguards, s/he said the following:

There is a current crisis in the world systems of rights, positive rights (legally recognized rights) against consuetudinary rights... It is not being properly taken into account many peoples' concerns of a better recognition of their own way of valuing their resources in terms of their custom, customary norms and customary law. Interviewee 4, National NGO.

Among ejidatarios themselves, perspectives were diverse and drew variously on a range of world views. However, the importance of maintaining livelihoods, traditional use, and traditional knowledge were recurrent themes among the ejidatorios interviewed.

For example, one ejidatario remarked on the abstract nature of sustainability and climate change discussions under REDD+, in contrast to his/her lived experience:

People talk about the REDD+ strategy [as referring to]
things very far from us, we see that far. But at the same
time we see it very close because we are already
experiencing climate change. (Interviewee 18,
Ejidatario, Quintana Roo; Inter-ejidal meeting in
Quintana Roo, 23 February 2013).

$\mathrm{S} /$ he was concerned about how climate change will affect the use of traditional knowledge. $\mathrm{S} /$ he considered that climate change, in particular extreme weather conditions and weather unpredictability, have increased the challenges of using traditional knowledge for weather forecasting, which has a direct impact on livelihood activities such as milpa management. However, $\mathrm{s} / \mathrm{he}$ also saw value in building on traditional knowledge for understanding and adapting to climate change:

It will be very hard to understand (climate change), the problem is to adapt... we need to change many things. We need especially to learn from the past because in the particular history of the Mayas there have been disasters... Our grandparents foresaw, bore all the natural disasters that happened with their own planning... (Interviewee 18, Ejidatario, Quintana Roo).

A representative of an organization of a group of forest ejidos also emphasized the importance of maintaining local livelihoods, and how this should not be sacrificed because of problems of climate change generated elsewhere:

... people who have no choice and cannot be compelled to sacrifice their food, their culture, their way of life because 
others do nothing or do very little. And I'm talking about countries that still retain their high consumption while thinking that others have to change it. (Interviewee 20, local organization of ejidos, Quintana Roo; Inter-ejidal meeting in Quintana Roo, 23 February 2013).

One community leader (in Interview 25) expressed appreciation for "pure" forest in a way that might seem to resonate with a No Touch perspective. However s/he held a different view than the CONANP interviewee on the causes of forest loss. In reference to the Sian Ka'an forest reserve, s/he said the following:

It is nice because nobody goes there, it is pure forest without roads for trucks, buses, coaches, motors, nothing... There are old trails that were used a lot for the extraction of chicle [A type of tree resin historically harvested both for local use and wider trade]. This is also a thing that the government did very badly, because they permitted the felling of zapote [the chicle tree]... this tree we should respect, also because it supports many forest animals.

This ejidatario also commented on problems with the changing composition of the ejido:

Other people from the Yucatan came and joined the ejido... they are giving us problems... because they don't obey, they are engaged in hunting, they are not dedicated to the land.

Consistent with the "local use and forest enterprise" world view, s/he discussed his/her own entrepreneurial activities:

After I harvested it I reforested this land with fruit and timber species, leaving it like it was before only, how shall we say, with value added. Because I know that everything I have costs. For example, the guano [Leafs of a palm tree used for construction, e.g., roofing material of huts], the price has appreciated after the hurricane, with the tourists, therefore we have bought the guano to put here. Now I believe it is five pesos per leaf.

S/he also expressed respect for traditional knowledge and livelihoods, while noting its absence among younger generations.

We grew up in a different era. Our era was very distinct... I have learned many things about crops that our fathers left us, we inherited. We never left for football, for other things, we dedicated ourselves to the farm, from when we were small... Now, until they are 15, 16 years old, they have computers... now the children can't do [their own] calculations, they can't do anything.

This diversity of perspectives clearly point in different directions in terms of what needs to be safeguarded from whom. They also signify divergent views on how REDD+ or any other intervention might best promote long-term sustainable forest management and community welfare. The following overview of REDD+ activities in our case study area will begin to identify which of these perspectives best fits with evolving REDD+ institutions.

\section{The setting of parameters for REDD+ in Ejido Felipe Carrillo Puerto}

Determining the scope of REDD+ activities

Much Kanan K'aax (MKK), which means "all of us working together to care for the forest" in the indigenous Mayan language, (from Interview 25) forms the center of REDD+ activity in ejido FCP. The focus of MKK is on forest recovery, through reforestation and agroforestry, and on avoided deforestation, through improving existing strategies of forest management and protection such as Community Conservation Areas (Proust 2011). According to interviewees involved in its inception, the idea for MKK emerged when local ejidal leaders approached a local NGO, U'yoolche, to enquire about opportunities to engage in carbon markets (Interviews 22, 25, 32). After ongoing discussions, FCP made a decision to work with U'yoolche to implement a carbon project under the auspices of Plan Vivo, an international carbon certification scheme. Reasons offered for the choice of Plan Vivo included its commitment to community-driven activities (Interview 22) and its relatively modest formal requirements (Interview 15). Although at the time of MKK's inception REDD+ had not yet been internationally agreed, Plan Vivo's community-based approach and emphasis on community benefit would appear to fit well with what were to become the REDD+ safeguards.

In 2011, and after UNFCCC agreement on REDD+, a Project Design Document (PDD) was submitted to Plan Vivo to launch Much Kanan K'aax in the Ejido Felipe Carrillo Puerto. The PDD states, furthermore, that the project has been recognized by CONAFOR as a pilot to inform the development of Mexico's national REDD+ strategy (Proust 2011). The project activities to be carried out were fallow enrichment through tree planting and avoided deforestation through the building of fire breaks and monitoring of fire and illegal forest encroachment (Proust 2011).

An area of 1230 ha was chosen to pilot MKK. This included 600 ha already enrolled in Mexico's hydrological Payment for Ecosystem Service scheme, overseen by the Mexican National Forestry Commission (CONAFOR). Mexico's PES scheme involves federal direct payments to individual landholders or communities (in the case of MKK) to maintain forest cover within approved conservation areas. ${ }^{[3]}$ Initially this PES scheme did not allow any active management activities (McAfee and Shapiro 2010). However, this rule was later changed to allow activities justified on the basis of nature conservation such as removal of diseased trees, construction of firebreaks, fencing against livestock, and patrolling against illegal logging, subject to approved management plans. Echoing the ongoing debates about REDD+ outlined above, the shift to allow management under the PES scheme appears to have been the result of pressure from civil society actors who objected to what they called a No Touch approach that failed to recognize the role of local farmers as land stewards (McAfee and Shapiro 2010). Although some limited "touching" was thus allowed, the current approach to PES in FCP is nevertheless still consistent with what we have labelled a No Touch perspective: the sole legitimating purpose is to protect the area in a "natural" state with "natural" being defined as free from human extractive activities. 
To qualify as a Plan Vivo carbon project, it was also necessary to demonstrate "additionality," that is, that MKK would lead to carbon storage and/or reduced emissions from what would otherwise have occurred. MKK thus added another 630 ha onto the total project area. Fifty ha of this additional area corresponded with the site of an ill-fated government-sponsored citrus project. Prior to the citrus project, the area had been covered in tall forest. This forest was cleared by the ejidatarios in anticipation of receiving citrus plants and training on their cultivation, neither of which materialized (Interviews 25, 15). The replanting of this area and the protection of the remaining forest area, much of which was accessible by road, thus were planned as additional activities to protect and enrich carbon storage.

The MKK project then sought and received certification for the entire 1230-ha project area as a Community Natural Protected Area (CNPA) through a program administered under the Natural Protected Area Commission (CONANP). CONANP is a deconcentrated organ of the Ministry of Environment (SEMARNAT). The certification was intended to demonstrate intent to conserve the forest for the purposes of obtaining financial resources, including through selling carbon (Interview $15)$.

At first glance, Plan Vivo, the federal PES scheme and CONANP's certification of the Community Natural Protected Area might all appear to provide a good institutional "fit" with REDD+ because all of these programs are committed to incentivizing local communities to maintain forest cover. However, as of the time of this research, FCP's attempts to achieve Plan Vivo certification had not succeeded and no carbon had been sold. U'yoolche respondents stated that the reason for the failure to achieve certification was a mismatch, i.e., institutional misfit, between the methods and intensity of site delineation and forest carbon monitoring they had conducted with support from CONAFOR, and Plan Vivo's requirements. FCP meanwhile lacked their own resources to invest in more intensive carbon monitoring (Interview 15). Nevertheless, the PES and CNPA certification schemes brought federal funding to support activities that were catalyzed by an interest in carbon markets and Plan Vivo certification. In this way the Plan Vivo process, whether or not it achieves a good institutional fit with the MRV systems supported by CONAFOR, has played an important role in generating REDD+ activity.

Since FCP's first attempt at Plan Vivo certification, other REDD+-related actions have also spun off of the initial MKK pilot. The area is part of the selected site in Yucatan for "REDD+ Early Action," an initiative executed by CONAFOR and the National Commission for Biodiversity (CONABIO) funded by the EU's Latin American Investment Fund (LAIF) and Norway (Interviews 12, 22 and 23). Specifically, with funding canalized through the United Nations Development Programme (UNDP), MKK would be used to pilot methodologies for "monitoring, reporting and verification" of forest carbon under Mexico's national REDD+ program (Interview 23; see also http://www. mrv.mx/index.php/en/news/blog/130-colaboracion-uyoolche-fcp. html). This includes the development of an intensive monitoring site located on three hectares of MKK reserve land. The aim of this site is to generate information on carbon monitoring (Interview 15), including biomass, forest structure, species composition, carbon dioxide flux from the ground, and organic carbon dissolved. The ejido also received certification from CONAFOR as a "certified instructor community" that was authorized to train other communities in carbon measurement and monitoring (see http://www.conafor.gob.mx:8080/documentos/ docs/37/4345Comunidades\%20Instructoras.pdf).

The World Bank funds "REDD+ Early Action" in the Yucatan as part of the "Mexico Forests and Climate Change Project" (World Bank 2011, 2014). The World Bank Report (2014) on the project's implementation status and results show that although the REDD+ Early Action activities concerning MRV and the reduction of net $\mathrm{CO}_{2}$ emissions had shown relative progress, there has been delay in fulfilling project objectives concerning community participation. The report also mentions that "there are still discussions within CONAFOR [on the meaning of] community-based, economically viable, REDD+ focussed, initiatives with demonstrated potential for replication at scale" (World Bank 2014:8).

This growth of these various carbon-oriented activities stands in contrast to FCP's involvement in forest product extraction. FCP is one among a number of ejidos in the Yucatan that have pursued forest certification under the FSC (FSC 2012), a scheme that includes environmental and social standards for responsible timber production. However, as of the time of this research, the ejido was facing a possible 10 -year prohibition on timber harvest because of apparent forest code violations (Interview 25) and the chances for FSC certification were slim. Commercial timber harvest in Mexico is heavily regulated (Hajjar et al. 2012, Vázquez and Fuente 2015) ${ }^{[4]}$, and this plus problems of organizational and technical capacity and economies of scale serve as major barriers to community-based operations hoping to access certification and associated lucrative timber markets (Klooster 2006).

If one views the failure of the timber venture in conjunction with the growth of carbon projects, it appears that REDD+ has been reinforcing a general trend toward carbon-focused and nonextractive activities within FCP. From the point of view of environmental fit the outcome in the FCP case would seem to fit best with the No Touch perspective, while creating a misfit with the Humans in Nature and Traditional Use perspectives.

This is not to say that all of the institutions relevant to REDD+ activities in FCP subscribe to the No Touch world view, either in ideology, or in official stated purpose. Indeed, at the national level, Mexico's 2010 "REDD+ Vision" places strong emphasis on rural development and support for community forestry and rural enterprise (CONAFOR 2010). Consistent with this vision, a recent review of Mexico's REDD+ readiness activities suggests deliberate efforts on the part of some REDD+ donors and institutions to support activities such as community forest production and agroforestry in the state of Quintano Roo in particular (Deschamps et al. 2015). Nevertheless, in 2012-2013 the REDD+ funds serving these categories represent a small fraction of all CONAFOR resources provided to eligible municipalities in Quintano Roo, with the Mexican PES scheme, followed by restoration and reforestation, still receiving the largest tranche of funds by a wide margin (Deschamps et al. 2015). Meanwhile at the national level, the 2016 Draft Budget of Expenditures of the Federation anticipates a cut of $40 \%$ of CONAFOR's operating budget, which would result in a 
significant reduction of the already limited staff supporting community forestry programs (Deschamps and Zúñiga 2015).

With regard to the impact of special REDD+ readiness funding on ejido FCP, as of the 2014 cut-off date of this study the ejido had received only one small grant for a single community forestry event (CONAFOR 2015). Meanwhile there are no functional, productive forestry or agricultural activities allowed in areas earmarked for REDD+ activities in ejido FCP. Instead, current REDD+ activities in FCP are adherent to the incentive structure of the Mexican PES scheme as the dominant implementing institution, and demonstrate a strong environmental fit with a No Touch perspective, and an environmental misfit with other world views.

Of course there are also other factors, besides REDD+ and the PES scheme, that may also play a role in explaining the de facto emphasis on nonextractive REDD+ activities in ejido FCP. The population density of the ejido is quite low, at 235 ha per ejidatario (EFCP 2005), which suggests a relatively low collective opportunity cost for the ejido to set aside land for carbon sequestration. Furthermore, interviewees identified a number of other social and economic challenges facing this and other ejidos in the Yucatan, such as youth outmigration, low timber and agricultural productivity, and communal reliance on a long history of government subsidies (Interviews 10, 15, 17, 18, 20, 26). With regard to the latter, the role of government subsidies in FCP is particularly ironic, given that the leading driver of deforestation in the REDD+ project area was the earlier government subsidized citrus project (Interviews 25, 15).

Nevertheless, to the degree that REDD+ is having any impact in ejido FCP, its net effect appears to be to further reduce the likelihood that alternative productive activities will be developed in the area. Furthermore, the location of the REDD+ project on communal land may also affect access for nonedjidal members. As will be discussed in the following section on safeguards, these nonejidal members hold no rights to the income from $P E S$ projects or carbon sales.

\section{Defining REDD+ safeguards}

Given that the scope of REDD+ in FCP has thus far been shaped largely by the Mexican PES scheme, we identify the range of safeguards and safeguarding institutions relevant to these REDD+ activities. Beginning at the local level, it was notable that local interviewees revealed little recognition or awareness of REDD+ safeguards, per se.

There are a number of possible reasons for this. One local interview noted that salvaguardas, the Spanish translation of "safeguards," is not a term used in everyday language. It is used even less by people for whom Spanish is not the first language and who have had limited formal education (Interview 18). A local NGO working with REDD+-related issues within the ejido FCP said that in discussing REDD+ information with community members they have not used the term safeguards, because it is not a concept of the people, "it is a World Bank concept... we see it (safeguards) more in terms of rights to land, rights to a healthy environment" (Interview 15).

REDD+ in general was associated more narrowly with activities involving subsidies or sales of forest carbon in conservation areas under the terms and conditions laid out by existing government and certification programs. However, as noted for example in the above Traditional Use quotes, existing Mayan traditions, systems of governance, and customary norms were seen by some as the best possible "safeguard" for all activities, REDD+ or otherwise.

At the international and national levels, meanwhile, a complex web of safeguards has been under development. The World Bank has played a major role in this web as a significant funder of the Mexican PES scheme and the Mexican National REDD+ strategy, the latter via the Forest Carbon Partnership Facility (FCPF) and Forest Investment Program (FIP). FCPF funding places significant emphasis on safeguards, and in particular compliance with the World Bank's own safeguards, which in turn overlap significantly with the REDD+ safeguards. For nationallevel initiatives like the Mexico REDD+ strategy, World Bank safeguards compliance is to be ensured through a Strategic Environmental and Social Assessment (SESA) and resulting Environmental and Social Management Framework (ESMF; McDermott et al. 2012).

The World Bank safeguards have also been relevant to the "Mexico Forests and Climate Change Project" (World Bank 2011) mentioned earlier in which a social assessment was carried out by CONAFOR with findings on "(i) the role of women in forest management; (ii) the identification of indigenous peoples in the project context; (iii) broad participation; (iv) out-migration; and (v) social conflicts" (World Bank 2011). According to an interviewee, it was a result of the World Bank safeguards that civil society organizations could request information from CONAFOR and demand that people's rights were respected (Interview 11).

The Mexico SESA, ESMF, and REDD+ Strategy were still not complete at the time of this research. Nevertheless, Mexico had already begun to institutionalize the REDD+ safeguards in its existing legal framework. Notably, there has been an addendum to various environmental laws, including the Law on Sustainable Forest Development (hereby referred to as the Forest Law), that incorporates central elements of the REDD+ safeguards. These include the requirement for free, prior, and informed consent for forest activities affecting ejidos, communidades (another form of communal ownership), and indigenous communities; "social plurality and participation" in forest decision making; and recognition of the right of forest owners and "legitimate possessors" to receive economic benefits from conserving or improving environmental services (Government of Mexico 2012). ${ }^{[5]}$ The concept of free, prior, and informed consent echoes that found in the UN Declaration on the Rights of Indigenous Peoples (UNDRIP), a declaration that is referenced in the UNFCCC REDD+ safeguards (see Box 1). The Forest Law also refers to Mexico's communal tenure arrangements, thereby clearly aligning the boundaries of free, prior, and informed consent within the country's existing land tenure system. In other words, at least in formal legal terms, the REDD+ safeguards have been precisely tailored to fit within Mexico's overall legal framework for forest ownership and governance (Workshop for the development of REDD safeguards in Mexico, 15 February 2013; Second legislative dialogue-workshop with communities, ejidos and indigenous peoples on forests and climate change, Deputies Chamber, 12 and 13 March 2013; Interview 2).

Mexico is also engaged with the REDD+ Social and Environmental Safeguards (REDD+ SES) program, an effort involving representatives of the Mexican national government 
Fig. 1. Key institutional actors and initiatives relevant to safeguarding REDD+ in Felipe Carrillo Puerto (FCP). This diagram illustrates key institutional actors involved in initiatives that currently affect or intend to affect the safeguarding of REDD+ in FCP. Intergovernmental and governmental actors are indicated by boxes with solid shading, donors by crosshatched boxes, and other institutional types (NGOs, a hybrid public/private organization, and an ejido assemblea) by boxes without shading. The diagram is not exhaustive; the extent and complexity of REDD+ and its associated safeguards is such that it is impossible to illustrate all potentially relevant institutions and activities and the relationships among them. Rather the purpose of this figure is to provide a graphic representation of the institutional dynamics discussed in this paper.

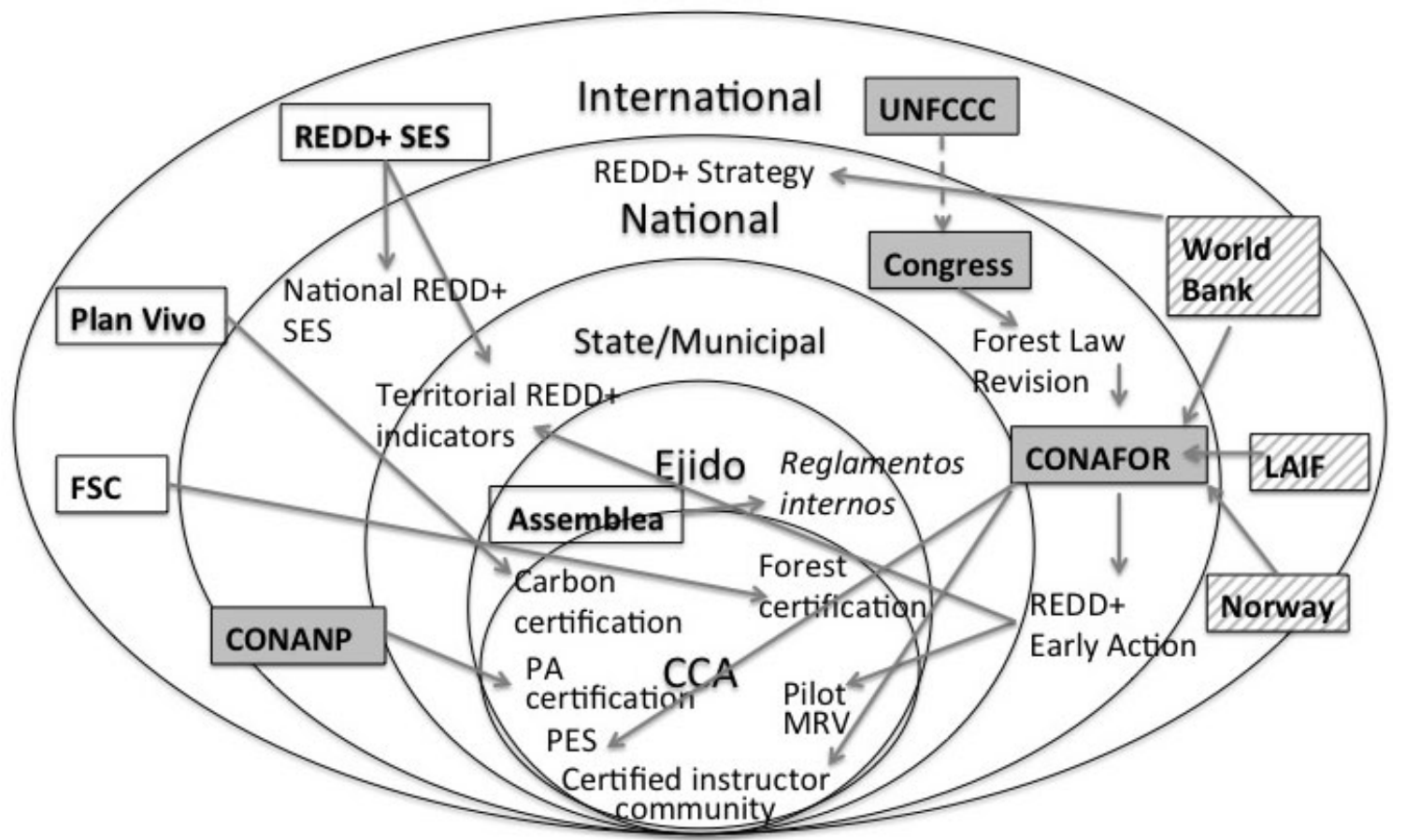

and the NGOs the Climate, Communities and Biodiversity Alliance (CCBA) certification scheme and CARE international. REDD+ SES is intended to assist governments in developing a REDD+ Safeguard Information System (SIS) that they can use to report on their performance on safeguards to the UNFCCC. Mexico chose to initiate this process at the intermunicipal level, and the Yucatan has formed its own intermunicipal working group that includes the town of Felipe Carrillo Puerto. The core international REDD + SES, which form the basis for these more local indicator processes, are notable for their strong and prescriptive language, outlining detailed requirements for free, prior and informed consent; full stakeholder participation; and measurable net benefits for local communities (McDermott et al. 2012). Part of the first steps of a REDD+ SES pilot project in Yucatan, which also aims to support the Yucatan Peninsula Regional REDD+ Strategy, is the establishment of a Committee of Safeguards Information Systems for REDD+. ${ }^{[6]}$ However the Mexican REDD+ SES process is still in its early stages and it is not yet clear if or how it will be taken up or adjusted to fit existing Mexican institutional arrangements.

Figure 1 summarizes all of the above activities in a map of institutions and actors relevant to REDD+ activities in FCP, and/ or social safeguarding under REDD + activities in FCP. Note that the Figure refers only to those institutions currently involved directly, or indirectly, in REDD+ activities within the ejido FCP. Given this complex landscape, the next section focuses on how institutional fit is shaping how these various REDD+-related safeguards are or are not being interpreted and implemented on the ground in FCP.

\section{The enactment of REDD+ safeguards in Ejido Felipe Carillo Puerto}

As discussed earlier, the MKK project has served as the locus of REDD+-related activities in FCP and the government agencies CONAFOR and CONANP have played key roles in both shaping and implementing these activities, including PES, Community Conservation Area certification, and various carbon monitoring activities. These government agencies are institutionally bound by a growing set of legislation, including the Mexican Constitution defining ejidal rights, as well as the new additions to the Forest Law requiring the free, prior, and informed consent of the ejido's Assembly for any projects that take place on ejido lands. The consent process, furthermore, is well defined by the ejido's own internal regulations. The result is that the REDD+ safeguard (c), relating to indigenous peoples and local community rights, and safeguard (d), relating to participation of relevant stakeholders, are being interpreted and implemented through the existing ejido Assembly system. 
The social implications of relying on Assembly governance to implement REDD+ are complex. On the one hand, Assembly members in FCP include economically disadvantaged Mayan indigenous community members, and in particular Mayan elders. Thus reinforcing the decision-making power of the Assemblies may help to counterbalance broader social inequalities. It also may fit well with the Traditional Use perspective on environmental challenges, to the degree that it empowers Mayan elders to practice and pass on their traditional knowledge to younger generations.

On the other hand, the Assembly system provides no guarantees of participation for the local community members who are not ejidatarios, and therefore cannot vote in the Assembly (Skutsch et al. 2013). Nonejido members include vulnerable groups such as women, younger generations who may or may not inherent ejidal rights, and migrants. For example only $20 \%$ of FCP's 200 ejidal members are women (EFCP 2005), and women are not traditionally included in the ejido's forest sector activities (Proust 2011). Likewise only $3 \%$ of ejidal members are between the ages of 18-30, while $79 \%$ are over 50 (EFCP 2005).

Safeguard (e) regarding social and environmental benefits presents even greater challenges. Here is where we found the clearest cases of conflict among the range of global to local stakeholder perspectives on what constitutes a sustainable livelihood and leads to long-term environmental enhancement. The current de facto focus of funding on carbon accounting and services and exclusion of extractive activities might be considered a good fit with sustainable livelihoods for those stakeholders who (1) ascribe to the No Touch world view outlined above and (2) are confident that the finance for carbon-related activities, and in particular carbon monitoring, will be sustained and/or generate other long-lasting livelihood alternatives into the foreseeable future. However, it does not fit well with either the Humans in Nature or Traditional Use world views. From these perspectives, sustainability and local welfare is best served through entrepreneurial use, including extractive use, of forest resources and/or reinvigoration of traditional forest practices.

It is important to note that interviews with FCP members did not reveal objections to this No Touch approach. This is to be expected, if the REDD+ procedural safeguards protecting community rights to free, prior and informed consent were indeed respected. However, of central importance to social equity is not simply whether local stakeholders chose to participate in the activities offered to them, but rather how institutions are shaping the range of options from which they could choose.

Along these lines, the findings for all three safeguards together highlight how the scope of safeguards to empower local actors is constrained when decisions, or parameter-setting, about what institutions will implement REDD+, what counts as a REDD+ activity, and who counts as a REDD+ stakeholder are made prior to local engagement. Furthermore, they suggest that the legal and procedural rights embedded in the REDD+ safeguards c) and d) are not sufficient to ensure that the REDD+ distributive benefits articulated in safeguard (e) reflect or articulate a balance of stakeholder perspectives. Rather, the distributive outcomes are constrained by the rules and norms of the dominant institutions involved in setting the parameters for REDD+ implementation. Essentially, although REDD+ activities in the study area appear to be reinforcing the right of ejidatorios to grant or deny their free, prior and informed consent to carbon projects, they are not providing equivalent resources and support to other local actors, or for other types of forest activities that may be more resonant with other local perspectives, knowledge systems, and customary norms. In other words, the right to say "no" to a narrow list of REDD+ activities is limited in its ability to empower local communities in shaping their own futures, unless there are a significant number of feasible alternatives to which they can say "yes."

These conclusions both echo but also build upon other studies that examine the relationship among contextual, procedural, and distributive equity (e.g., Chhatre et al. 2012, Mahanty and McDermott 2013, McDermott et al. 2013); as well as the relationships between procedural and substantive dimensions of law in the governance of social-ecological systems (e.g., Ebbesson and Hey 2013). That is, our conclusions not only emphasize their inter-related nature, but they raise questions about the environmental and social effectiveness of focusing on procedural rights while failing to explicitly interrogate and address underlying normative assumptions about appropriate pathways to sustainability.

\section{CONCLUSION}

This study provides a detailed, multiscale perspective on the enactment of REDD+ and its safeguards in a single ejido in Mexico's Yucatan Peninsula. Given the diversity of REDD+ institutions from global to local scales, and the diversity of Mexican contexts, the precise constellation of institutions and policies shaping REDD+ activities in this case should not be viewed as "typical" Rather, what this multiscale approach has allowed is a more in-depth understanding of the processes by which REDD+ goals and objectives are transposed from global to national to local levels, and how institutional factors set the parameters and constrain the options actually available on the ground.

The findings have identified, first, a wide range of perspectives among Mexican REDD+ stakeholders regarding what types of actions will contribute to long-term forest conservation and community well-being. Within this range we identified three indicative types, consisting of a No Touch (strict conservation, no extractive activities) perspective, a Humans in Nature (local entrepreneurship and use it or lose it) perspective, and a Traditional Use perspective.

We found institutional fit to be critical in shaping the design of REDD+-related activities in our case study area. This in turn has had significant implications for environmental fit, i.e., which visions of sustainability are reinforced or undermined. Although Mexico's REDD+ Vision, and the stated goals of international donors and carbon certification schemes, may support a diversity of local livelihood activities under REDD+, the choices actually available to FCP were constrained by the rules and priorities of existing REDD+ implementing institutions and policies. In our study area, REDD+ activities had strong institutional links to Mexico's PES scheme and international donor-funded carbon MRV activities. The PES scheme promoted nonextractive activities consistent with a No Touch perspective, and inconsistent with the Humans in Nature and Traditional Use perspectives. The MRV activities were likewise located within the PES scheme area, and focused almost exclusively on carbon accounting. 
Both institutional and environmental fit, in turn, influence the interpretation and enactment of safeguards. We found low recognition of the concept of safeguards among the local stakeholders interviewed. Consistent with this, safeguards implementation was not explicit, but rather was embedded in existing Mexican institutions. In particular, the existence of strong and relatively well-defined procedures for community participation and consent within the Mexican ejidal system, a system recognized within the Mexican Constitution, was further reinforced through recent integration of REDD+ safeguards into environmental law, and contributed to the enactment of relatively strong procedural rights. It also served to equate the more broadly framed REDD+ language around indigenous peoples and local rights and participation with the rights and processes institutionalized within the ejidal system. This might be a seen as a positive step toward procedural equity, given that our case study ejido includes economically disadvantaged groups in its membership, including Mayan elders. However, it also excluded others, such as many females, youths, and migrants.

Meanwhile, the focus of REDD+ safeguards on procedural rights obscured the broader institutional context in which REDD+ is taking place, a context that may favor some constructions of sustainability (No Touch) over others (Humans in Nature and Traditional Use). The interpretation of REDD+ safeguard (e) referring to environmental and social benefits, is in part bound by normative assumptions about what actions will, or will not, lead to long-term forest conservation and community well-being. These include the normative priorities of those involved in REDD+ parameter-setting, i.e., those engaged in defining REDD+ at the international and national level. However, whatever the priorities agreed in these higher policy arenas, the translation of REDD+ safeguards on the ground is also constrained by the technical requirements and interests of those implementing REDD+, from the Plan Vivo auditors bound by international auditing standards, to local forest officers charged with enforcing complex forest laws. Procedural safeguards, such as free, prior, and informed consent, that reinforce community rights and participation to accept or reject No Touch REDD+ activities are not by themselves sufficient to empower communities to pursue their own visions of a sustainable future. Such empowerment, instead, would require that similar institutional support be provided for communities to shape and realize their own visions of sustainability.

Regardless of whether one holds a No Touch view, there is plenty of room to debate whether the current exclusive focus of REDD+ in this ejido on carbon storage and monitoring is sustainable in the long run. In our FCP case study, attempts to certify and sell carbon credits in voluntary markets have thus far failed. Even if these efforts eventually succeed, there is no guarantee that such sales will yield good prices (Peters-Stanley and González 2014). The Mexican PES scheme has proven more reliable in generating modest revenue, but there are no guarantees of its political future either. Although recent years have seen high levels of national and international interest in piloting REDD+ MRV, it is unlikely this interest will be sustained indefinitely as methodologies become institutionalized and/or political priorities move elsewhere.

Meanwhile, REDD+ interventions combined with legal and institutional barriers to timber harvest seem to be reinforcing the general shift in the community noted by the Mayan elder above, that is, a shift away from working and spending time on the farm and in the forest. This raises much more fundamental questions about the possibilities of reconnecting to local life support systems, understood as locally evolved and adapted systems for sustaining livelihoods and well-being embedded in the local environment, and developing sustainable pathways that are in tune with the planet of which we are part (Folke and Gunderson 2012). For example, research on "ecological footprints" adopts a global perspective on sustainability that questions the overall impacts of different lifestyles and livelihoods. One such study examined a Mexican poverty alleviation scheme involving cash transfers to farmers (Alix-Garcia et al. 2013). Similar to a No Touch REDD+ approach, this scheme helped to shift farmers away from land-based activities. It also succeeded in raising average incomes leading to a corresponding increase in household consumption of land-intensive goods associated with deforestation elsewhere. In other words, from a global perspective, traditional land uses may be much more sustainable than those practiced by the majority of the developed world. A greener and more just world may require rethinking the relationship between humans and the land and ecosystems that sustains us including paying proper attention to the interaction and dynamics between various scales of social-ecological systems and governance contexts (Galaz et al. 2008, Ebbesson and Folke 2014).

In sum, our findings highlight the importance of revisiting the underlying assumptions about sustainability that are currently driving REDD+ activities, and considering how the choice of REDD+ institutions will influence these assumptions. It also highlights the importance of grounding discussions about REDD+ safeguards in local realities. Such efforts are critical, if REDD+ safeguards are to empower indigenous peoples and local communities to participate meaningfully in REDD+ in ways that will ensure long-term net environmental and social benefit.

\section{Responses to this article can be read online at: http://www.ecologyandsociety.org/issues/responses. $\mathrm{php} / 8088$}

\section{Acknowledgments:}

The authors would also like to express gratitude to the people who participated in the interviews, focus groups, and REDD+ related meetings in the Yucatan Peninsula and Mexico City, for their generous and insightful contributions to this research. Research for this paper was funded by the John Fell Fund, University of Oxford through the project "Qualifying carbon: building trust and credibility in REDD+ through reflexive, multi-level governance." It is also an output of the project "Effective and Equitable Institutional Arrangements for Financing and Safeguarding Biodiversity" funded by The Swedish Research Council for Environment, Agricultural Sciences and Spatial Planning (Formas).

\section{LITERATURE CITED}

Alix-Garcia, J., C. McIntosh, K. R. E. Sims, and J. R. Welch. 2013. The ecological footprint of poverty alleviation: evidence from Mexico's Oportunidades Program. Review of Economics and Statistics 95:417-435. http://dx.doi.org/10.1162/REST a 00349 
Bromley, D. W. 2012. Environmental governance as stochastic belief updating: crafting rules to live by. Ecology and Society 17 (3):14. http://dx.doi.org/10.5751/es-04774-170314

Chhatre, A., S. Lakhanpal, A. M. Larson, F. Nelson, H. Ojha, and J. Rao. 2012. Social safeguards and co-benefits in REDD+: a review of the adjacent possible. Current Opinion in Environmental Sustainability 4:654-660. http://dx.doi.org/10.1016/ j.cosust.2012.08.006

Clapp, J., and P. Dauvergne. 2005. Paths to a green world : the political economy of the global environment. MIT Press, Cambridge, Massachusetts, USA.

Comisión Nacional Forestal (CONAFOR). 2010. Visioón de México sobre REDD+. CONAFOR, SEMARNAT, Gobierno Federal, Mexico City, Mexico.

Comisión Nacional Forestal (CONAFOR). 2015. CONAFOR Subsidies 2010 - 2014. CONAFOR, SEMARNAT, Gobierno Federal, Mexico City, Mexico.

Corbera, E., and K. Brown. 2008. Building institutions to trade ecosystem services: marketing forest carbon in Mexico. World Development 36:1956-1979. http://dx.doi.org/10.1016/j. worlddev.2007.09.010

Cox, M. 2012. Diagnosing institutional fit: a formal perspective. Ecology and Society 17(4):54. http://dx.doi.org/10.5751/ es-05173-170454

Deschamps, P., B. Zavariz, and I. Zúñiga. 2015. Review of REDD+ implementation in Mexico: analysis of the special programs and early action areas. Consejo Civil Mexicano para la Silvicultura Sostenible A.C. (CCMS), Mexico City, Mexico.

Deschamps, P. and I. Zúñiga. 2015. Nota informativa 43: Presupuesto forestal 2016: Nuevos riesgos para los bosques. Consejo Civil Mexicano para la Silvicultura Sostenible A.C. (CCMS), Mexico City, Mexico.

Ebbesson, J., and C. Folke. 2014. Matching scales of law with social-ecological contexts to promote resilience. Pages 265-292 in A. S. Garmestani and C. R. Allen, editors. Social-ecological resilience and law. Columbia University Press, New York, New York, USA.

Ebbesson, J., and E. Hey. 2013. Introduction: Where in law is social-ecological resilience? Ecology and Society 18(3):25. http:// dx.doi.org/10.5751/ES-05750-180325

Ejido de Felipe Carillo Puerto (EFCP). 2005. Estudio de Ordenamiento Territorial del Ejido Felipe Carrillo Puerto. EFCP, Felipe Carrillo Puerto, Quintana Roo, Mexico.

Eliasch, J. 2008. Eliasch review: climate change: financing global forests. UK Office of Climate Change, London, UK.

Epstein, G., J. Pittman, S. M. Alexander, S. Berdej, T. Dyck, U. Kreitmair, K. J. Rathwell, S. Villamayor-Tomas, J. Vogt, and D. Armitage. 2015. Institutional fit and the sustainability of socialecological systems. Current Opinion in Environmental Sustainability 14:34-40. http://dx.doi.org/10.1016/j.cosust.2015.03.005

Folke, C., and L. Gunderson. 2012. Reconnecting to the biosphere: a social-ecological renaissance. Ecology and Society 17 (4):55. http://dx.doi.org/10.5751/ES-05517-170455
Fondo Nacional de Financiamiento Forestal (FONAFIFO), Comisión Nacional Forestal (CONAFOR) and Ministry of Environment. 2012. Lessons Learned for REDD+ from PES and Conservation Incentive Programs. Examples from Costa Rica, Mexico, and Ecuador. FONAFIFO, CONAFOR, the Ecuador Ministry of the Environment, Forest Trends, the Forest Carbon Partnership Facility, and the Latin American and Caribbean Region of the World Bank.

Forest Stewardship Council (FSC). 2012. FSC certificate database. FSC, Bonn, Germany. [online] URL: http://info.fsc.org/ certificate.php

Galaz, V., P. Olsson, T. Hahn, C. Folke and U. Svedin. 2008. The problem of fit among biophysical systems, environmental and resource regimes, and broader governance systems: insights and emerging challenges. Pages 147-182 in O. R. Young, L. A. King, and $\mathrm{H}$. Schoeder, editors. Institutions and environmental change: principal findings, applications, and research frontiers. MIT Press, Cambridge, Massachusetts, USA. http://dx.doi.org/10.7551/ mitpress/9780262240574.003.0005

Gómez, M. 2011. Una simulación jurídica. La Jornada, 12 March. [online] URL: http://www.jornada.unam.mx/2011/03/12/oja167simulacion.html

Government of Mexico. 2011. Que Eexpide la Ley General de Consulta a los Pueblos y Comunidades Indílgenas a Cargo del Diputado Teófilo Manuel García Corpus del Grupo Parlamentatio del Pri. Government of Mexico, Mexico City, Mexico. [online] URL: http://sil.gobernacion.gob.mx/Archivos/Documentos/2011/12/ asun_2826940_20111201_1322758439.pdf"

Government of Mexico. 2012. Reforms to the Ley General del Equilibrio Ecológico y la Protección Ambiente y de la Ley General de Desarrollo Forestal Sustentable. Government of Mexico, Mexico City, Mexico.

Hajjar, R. F., R. A. Kozak, and J. L. Innes. 2012. Is decentralization leading to "real" decision-making power for forest-dependent communities? Case studies from Mexico and Brazil. Ecology and Society 17(1):12. http://dx.doi.org/10.5751/ es-04570-170112

Ituarte-Lima, C., C. L. McDermott, and M. Mulyani. 2014. Assessing equity in national legal frameworks for REDD+: the case of Indonesia. Environmental Science and Policy 44:291-300. http://dx.doi.org/10.1016/j.envsci.2014.04.003

Klooster, D. 2006. Environmental certification of forests in Mexico: the political ecology of a nongovernmental market intervention. Annals of the Association of American Geographers 96:541-565. http://dx.doi.org/10.1111/j.1467-8306.2006.00705.x

Mahanty, S., and C. L. McDermott. 2013. How does 'free, prior and informed consent' (FPIC) impact social equity? Lessons from mining and forestry and their implications for REDD+. Land Use Policy 35:406-416. http://dx.doi.org/10.1016/j.landusepol.2013.06.014

March, J. G., and J. P. Olsen. 1983. The new institutionalism: organizational factors in political life. American Political Science Review 78:734-749. http://dx.doi.org/10.2307/1961840

McAfee, K., and E. N. Shapiro. 2010. Payments for ecosystem services in Mexico: nature, neoliberalism, social movements, and 
the state. Annals of the Association of American Geographers 100:579-599. http://dx.doi.org/10.1080/00045601003794833

McDermott, C. L., L. Coad, A. Helfgott, and H. Schroeder. 2012. Operationalizing social safeguards in REDD+: actors, interests and ideas. Environmental Science and Policy 21:63-72. http://dx. doi.org/10.1016/j.envsci.2012.02.007

McDermott, M., S. Mahanty, and K. Schreckenberg. 2013. Examining equity: a multidimensional framework for assessing equity in payments for ecosystem services. Environmental Science and Policy 33:416-427. http://dx.doi.org/10.1016/j.envsci.2012.10.006

Munoz-Pina, C., A. Guevara, J. M. Torres, and J. Brana. 2005. Paying for the hydrological services of Mexico's forests: analysis, negotiations and results. Instituto Nacional de Ecología, Mexico.

Osborne, T. M. 2011. Carbon forestry and agrarian change: access and land control in a Mexican rainforest. Journal of Peasant Studies 38:859-883. http://dx.doi.org/10.1080/03066150.2011.611281

Peters-Stanley, M. and G. González. 2014. Sharing the stage: state of the voluntary carbon markets 2014: Executive summary. Forest Trends' Ecosystem Marketplace, Washington, D.C., USA.

Powell, W. W., and P. G. DiMaggio, editors. 1991. The new institutionalism in organizational analysis. The University of Chicago Press, Chicago, Illinois, USA.

Proust, S. 2011. Plan Vivo Project Design Document (PDD) Much Kanan K'aax. U'yolche, Felipe Carrillo Puerto, Quintana Roo, Mexico.

Sikor, T., J. Stahl, T. Enters, J. C. Ribot, N. Singh, W. D. Sunderlin, and L. Wollenberg. 2010. REDD-plus, forest people's rights and nested climate governance. Global Environmental Change 20:423-425. http://dx.doi.org/10.1016/j.gloenvcha.2010.04.007

Skutsch, M., C. Simon, A. Velazquez, and J. C. Fernández. 2013. Rights to carbon and payments for services rendered under REDD+: options for the case of Mexico. Global Environmental Change 23:813-825. http://dx.doi.org/10.1016/j.gloenvcha.2013.02.015

Stern, N. 2007. The economics of climate change: executive summary. UK Department of Energy and Climate Change, London, UK. [online] URL: http://www.wwf.se/source. php/1169157/Stern\%20Report_Exec\%20Summary.pdf

UN Framework Convention on Climate Change (UNFCCC). 2011. The Cancun Agreements Dec 1/CP.16. UNFCCC, Cancun, Mexico.

UN Framework Convention on Climate Change/Ad hoc Working Group on Long-term Cooperative Action (UNFCCC/ AWGLCA). 2011. Report of the Conference of the Parties on its sixteenth session, held in Cancun from 29 November to 10 December 2010. UNFCCC/AWGLCA, Cancun, Mexico.

Vatn, A., and P. Vedeld. 2012. Fit, interplay, and scale: a diagnosis. Ecology and Society 17(4):12. http://dx.doi.org/10.5751/ es-05022-170412

Vázquez, E. F., and N. M. Fuente. 2015. Sobrerregulación Forestal: Un obstáculo para el desarrollo sustentable de México. Consejo Civil Mexicano para la Silvicultura Sostenible A.C., Mexico.
Visseren-Hamakers, I. J., C. McDermott, M. J. Vijge, and B. Cashore. 2012. Trade-offs, co-benefits and safeguards: current debates on the breadth of REDD+. Current Opinion in Environmental Sustainability 4:646-653. http://dx.doi.org/10.1016/ j.cosust.2012.10.005

World Bank. 2011. Integrated safeguards datasheet: appraisal stage. World Bank, Washington, D.C., USA. [online] URL: $\underline{\text { http:// }}$ www-wds.worldbank.org/external/default/WDSContentServer/WDSP/ IB/2011/11/23/000020953 20111123110959/Rendered/ INDEX/657570ISDS0MX0forests0and0climate0rev.txt

World Bank. 2014. Implementation status \& results: Mexico: Mexico forests and climate change project (P123760). World Bank, Washington, D.C., USA. [online] URL: http://www-wds. worldbank.org/external/default/WDSContentServer/WDSP/ LCR/2014/07/01/090224b08254e43d/1_0/Rendered/PDF/ Mexico000Mexic0Report000Sequence005.pdf

Wright, P. M., and S. A. Snell. 1998. Toward a unifying framework for exploring fit and flexibility in strategic human resource management. Academy of Management Review 23:756-772.

Young, O. R. 2002. The institutional dimensions of environmental change: fit, interplay, and scale. MIT Press, Cambridge, Massachusetts, USA.

Young, O. R., L. A. King, and H. Schroeder. 2008. Institutions and environmental change: principle findings, applications, and research frontiers. MIT Press, Cambridge, Massachusetts, USA. http://dx.doi.org/10.7551/mitpress/9780262240574.001.0001 